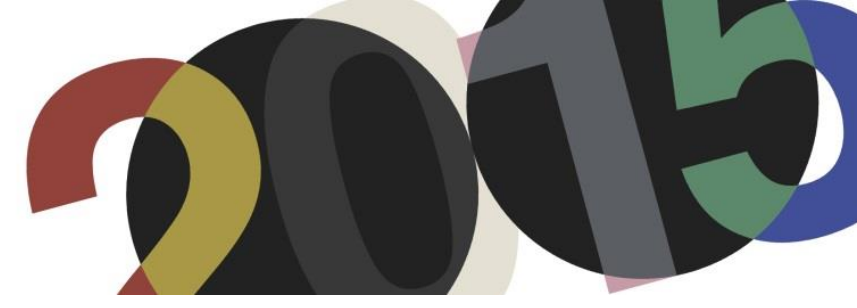

DOI: http://dx.doi.org/10.4995/LC2015.2015.799

\title{
Mapping the Stylistic Affiliations of Le Corbusier's Work
}

\author{
P. Ilias Panigyrakis
}

TU Delft, School of Architecture and the Built Environment

\begin{abstract}
The paper deals with Le Corbusier's connection to the term "style". A classification of his work in specific architectural styles is discussed, followed by a description of the procedure through which the style of the man Le Corbusier was constructed; in an attempt to search meaning in his continual stylistic shifts and the rationale that kept his lifetime's work and identity strongly compact when we consider him retrospectively.
\end{abstract}

Resumen: El artículo trata la conexión de Le Corbusier con el término ëstilo." Se discute una clasificación de su obra en estilos arquitectónicos específicos, seguido de una descripción de los procedimientos a través del cual el hombre fue construido al estilo de Le Corbusier; un intento de búsqueda de sentido en sus cambios estilísticos continuas y las razones que mantuvo el trabajo y la identidad de su vida fuertemente compacta, cuando lo consideramos retrospectivamente

Keywords: Le Corbusier; Style; Stylistic Shifts.

Palabras clave: Le Corbusier; Estilo; Cambios Estilísticos.

\subsection{Prologue}

It is said that Le Corbusier used to keep a picture of his 1914 Maison Dom-ino scheme side by side with a picture of the Parthenon from his 1911 visit in Athens. It is also known that he viciously fought against the talk of styles in the architectural discourse. How should we interpret then the above mentioned coupling of Dom-ino, the epitome of technique of the 20th century architecture, along with the Parthenon, the most imitated object of any iconographic style prior to Modernism? This research will argue for the stylistic affiliations of Le Corbusier's work in an attempt to map the trajectory of architectural forms applied in the extensive work of the legendary architect.

In his 1936 Oeuvre Complete, Le Corbusier writes:

"In a hundred years we could speak of a "style". We should not do so today, but only of STYLE, which is, the moral tendency of any work created, truly created ${ }^{l}$."

It is here clearly stated that although Le Corbusier's name was strictly affiliated with Modernism's moralistic arguments against 19th century's affluence of styles and formalistic expressions, he strongly sustained an artistic approach towards the architectural form, not unlike his painting aspirations, thus in stylistic terms. Several styles have been clearly used by Le Corbusier in his career of sixty years: from the regional styles of La Chaux-deFonds and the Villa Savoye's strict Modernism until Ronchamp chapel's formalistic excess and 1950's brutalistic experiments. Even on one of his final schemes, the 1965 Venice hospital, Le Corbusier showcased his

\footnotetext{
1 “Dans cent ans, nous pourrons parler d'un 'style'. Il n' en faut pas aujourd' hui, mais seulement DU STYLE, c'est-à-dire de la tenue morale dans toute oeuvre créée, veritablement créée."

Le Corbusier, Le Corbusier et Pierre Jeanneret, Oeuvre Complète: 1910-1929, Paris: Les Editions d' Architecture, 1936, pp.2.
} 
flexible formalistic capability, borrowing from the structuralist style of his 30-years younger, Candilys' compositions. Style, as a term aims for the systematic approach towards the artistic creation2. However, although the 19th century architectural theoreticians went through great pains to define a methodological approach towards architectural styles, since the dawn of Modernism it has been abolished from architecture's critical analysis3. This however does not mean that it was not continuously used in terms of the architectural practice. The correspondence between architectural form and extrinsic factors is that which posits it as an "undiscussed, self-evident" analytical tool upon which our historical consciousness is based ${ }^{4}$. It is this basic role of style for the ordering of historiography that establishes its use essential for the relevance of produced innovative works. And although modernist rhetoric denounced style as an operative motive, the production of style has provided the organizing factor and orienting framework for the social production of the architectural discipline $^{5}$ that is currently re-emerging, in relation to the social changes of the second half of the 20th century characterizing architecture's development with its immediacy ${ }^{6}$.

\subsection{Objectives}

The objectives of this research would be to point out, in architectural terms, the "STYLE" or "styles" used by Le Corbusier.

- What defined his stylistic periods?

- What were the reasons for his recurring stylistic shifts?

- How did he structured his personal image, and to what extent this affected his stylistic engagements?

- What role did his careful post-production played in the formation of his work's image?

\subsection{Methodology}

The research will be organized in two parts, dealing with two aspects of style a) towards his work and b) Le Corbusier himself.

○ Le Corbusier: The Architectural Styles: The first part will deal with the classification of his architectural work in specific stylistic groups as well as his linkage to wider stylistic movements. The built architectural projects will be chronologically presented, noting his projects that proved to be pivotal to his stylistic shifts. Moreover, a short comments will be made on Le Corbusier's main design or constructional inventions in order to observe to what degree these innovations shaped his stylistic endorsements throughout his architectural career.

○ Le Corbusier: The Style of the Man: The second part will deal, more generally, with Le Corbusier's personal style of appearance, tracing an overview of his wide spectrum of coinciding interests that structured his persona as a sophisticated artist. His unceasing passing through multiple design and knowledge fields will be put in perspective with the structuring of his image, along with other factors that shaped his figure such as: his careful post-production of his work, his participation and direction of exhibitions and associations as well as his numerous publications.

\footnotetext{
${ }^{2}$ Schapiro, Meyer, Theory and Philosophy of art: Style, Artist and Society, George Braziller, Inc., New York, 1994.

${ }^{3}$ Bakel, Anton Paulus Maria von, Styles of Architectural Designing: Empirical Research on Working Styles and Personality Dispositions, Ph.D. submitted at the Technische Universiteit Eindhoven, 2009.

${ }^{4}$ Makkreel, Dilthey, Philosopher of the Human Studies, Princeton, Princeton University Press, 1992.

${ }^{5}$ Brain, David, "Discipline and Style: The Beaux Arts and the Social Reproduction of an American Architecture". In Theory and Society vol.18. Berlin: Springer,1989. pp. 807.

${ }^{6}$ Hvattum, Mari, "Crisis and Correspondence: Style in the Nineteenth Century".In Architectural Histories, vol 1, EAHN, Zurich, 2013. pp. 1-8.
} 
○ Style by Le Corbusier: In conclusion, a short note will be made on Le Corbusier's personal attitude towards the notion of style.

LE CORBUSIER /CHARLES EDOUARD JEANNERET

ARCHITECTURAL STYLES

$1887-7965$
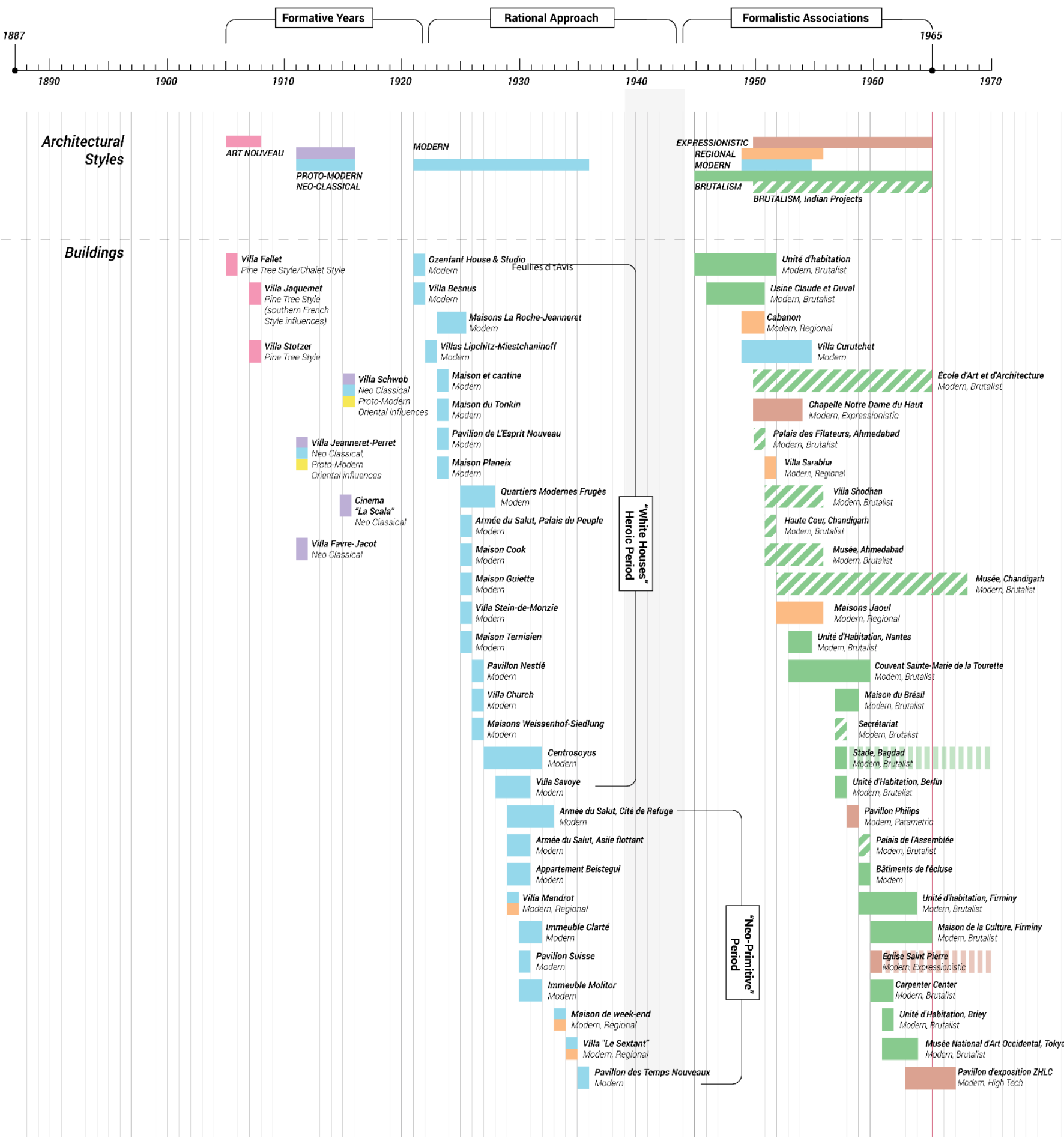

1. Classification of Le Corbusier's buildings during his lifetime corresponding to architectural styles and periods. 


\section{Part 1. Le Corbusier: The Architectural Styles}

Le Corbusier's total work is usually summed up in 3 periods that subsequently typify his early, mature and late work, throughout the years: A) 1887-1922, B) 1922-1944 and C) 1944-1965 ${ }^{7}$. This study will attempt to address these periods through an analysis of the principles that Le Corbusier posed as his basic starting points for his architecture and the different formal characteristics of his styles.

\subsection{The Formative Years (1887-1922)}

This first period could be characterized as Proto-Modern. The elements of the architectural vernacular that Le Corbusier deemed dominant were gradually simplified towards a new direction that allowed modernism to emerge. Regional, Art Nouveau and Neo-classical were mutated stylistically losing their cohesion with the motives that generated them: local elements wore off, contradiction between art nouveau and industry climaxed and neo-classical doctrines seemed all too distanced.

Le Corbusier's early years were marked by his largely influential roots in his upbringing at La Chaux-de-Fonds. The regional styles of the area, as well as the popular Art Nouveaux styles of the epoch do appear in Charles Jeanneret's first works. His very first contribution to designing a building at the early age of 17, was the Villa Fallet, in the "pine tree style" (style sapin) a regional art nouveau ramification that was popularized by the La Chaux-de-Fonds Art School, founded by Jeanneret's mentor and teacher, L'Eplattenier. The style bared heavy influences from the chalet style of the alpine vernacular architecture that was also applied in his 1917 Villa Jaquemet and Villa Stotzer ${ }^{8}$.

Jeanneret's subsequent travels in Vienna and Budapest introduced him to the styles of the Jugendstil and the Viennese Secession. His short employment under Auguste Perret in Paris and under Peter Behrens in Berlin also sparked new influences in subsequent villas Jeanneret built in his hometown, now in a much more innovative approach. The Villa built for his parents does merge the regional Art Nouveau tendencies with early protomodernist forms such as the ones deployed by Perret or Behrens merged with neo-classical experiments. On the contrary the subsequent Villa Schwobb, or Villa Turque, carries clear oriental characteristics, probably inspired by his 1911 journey to the east; proving that Le Corbusier was already expanding his vocabulary beyond his patrons' teachings, in search now of a style of his own'. While the regional styles of Chaux-de-Fonds provided young Jeanneret with the basis for his artistic and constructional beginnings it was the early modernist styles of his mentors that affected his departure for a search of a modern aesthetic. The journey to the East had limited influence on his work, with Villa Schwobb being the only clearly "oriental" project of this period. It was more in a cultural level that we can trace the effect of the oriental vernacular styles in the architect's new strongly held beliefs of the need for human society to reconnect with the natural world, and the importance of finding a new form of sacred or spiritual experience for the skeptical world of the $20^{\text {th }}$ century, industrialized West ${ }^{10}$. Although his later involvement with the technological advances of the machine age is well acknowledged it is important to note his equally strong interest from his early years in the low-tech and the vernacular styles that would later reappear with a leading role in his more mature period.

\footnotetext{
${ }^{7}$ This periodization is taken from: Curtis, Wiliam, Le Corbusier: Ideas and Forms, Phaidon, 1980.

${ }^{8}$ Lowman, Joyce, Le Corbusier 1900-1925: The Years of Transition, Ph.D. submitted at the University College of London, 1981, pp 60.

9 ibid, pp 54

${ }^{10}$ Dummet, Emma, Vernacular Architecture, nature and the sacred: Le Corbusier and the influence of the 'journey to the east. In eSharp Issue 4. Glasgow: University of Glasgow Publications, Spring 2005.
} 
The year 1917, marks for Le Corbusier a new beginning, ending the confusing styles of the "La Chaux-de-Fonds years of 1900-1917" and leading to more precise stylistic endorsements. With the exemption of the "Maison Dom-ino" of 1914 conceived with Max Dubois, it was mainly his Paris years of 1917-1922 that laid the foundation for the architectural style that brought him in mainstream acknowledgement: the original Modern Style of the 1920's.

Throughout these years (1917-22), the Dom-ino house of the years 1914/15 evolved to a series of residential projects centered on the concept of a repeatable unit formed by a prefabricated skeleton without strict standardized program. This scheme produced several variants such as: the "Troyes", 1919 (houses of grosbeton), the "Monol" houses, 1920 and the "Citrohan" houses that spanned almost a decade of variations (19191927) until the realization of one of them, in the Weissenhofsiedlung in Stuttgart. Although this series of projects could not be argued to consist a style of their own, in retrospect it is evident that this line of projects led to the 5points of his new architecture that provided the promoting rhetoric of the structural prototype of the Dom-ino and led to its culmination in the characteristic style of his 1920's white houses. It is also debatable that the 1919 perspective of the Dom-ino house provided not only the concept but also formal features to his modern style, such us:

- the fascination with the voluminous space that concrete and metal could generate

- the emphasis on transparency

- the sanctioning of movement

- and the exhibition of technology and structure as artistic elements

The year when Le Corbusier would put his projects into test and start structuring his style, was 1922 when his first commissions in Paris finally resulted in built projects.

\subsection{The Rational Approach (1922-1944)}

The Heroic Era of the 1920's marked Le Corbusier as the principle instigator of the modern architectural movement. To quote Philip Johnson, "Le Corbusier was the man who first made the world that a new style was being born" $"$. Although the importance of the role of other architects in establishing the "International Style" was recognized, Le Corbusier held by himself an adequate collection of projects that portrayed the whole spectrum of this new style's implementations in his work alone. A) His series of "white houses" tested the former experiments of the Dom-ino archetype in specificities of building materials, constructional techniques, clients' preferences, different budgets and topographic particularities. B) In addition, a different approach to the Modern Style was inspected through a series of social housing projects that featured more subtle forms and provided the urbanistic vision, the context for this style's formalistic endeavors as well as its moralistic basis. C) A third category of this period could be discerned in three pavilions that were built for exhibitions such as the Neslté Pavilion exhibiting another aspect of the modern style: the flexibility that it could acquire adapting to time limitations, social events and the use of demountable structures. In all these three categories underline the A) sophisticated, B) simplified and C) light versions of the modern style.

${ }^{11}$ Hitchcock, H.R.; Johnson P. The International Style: Architecture since 1922. , New York: 1932. 


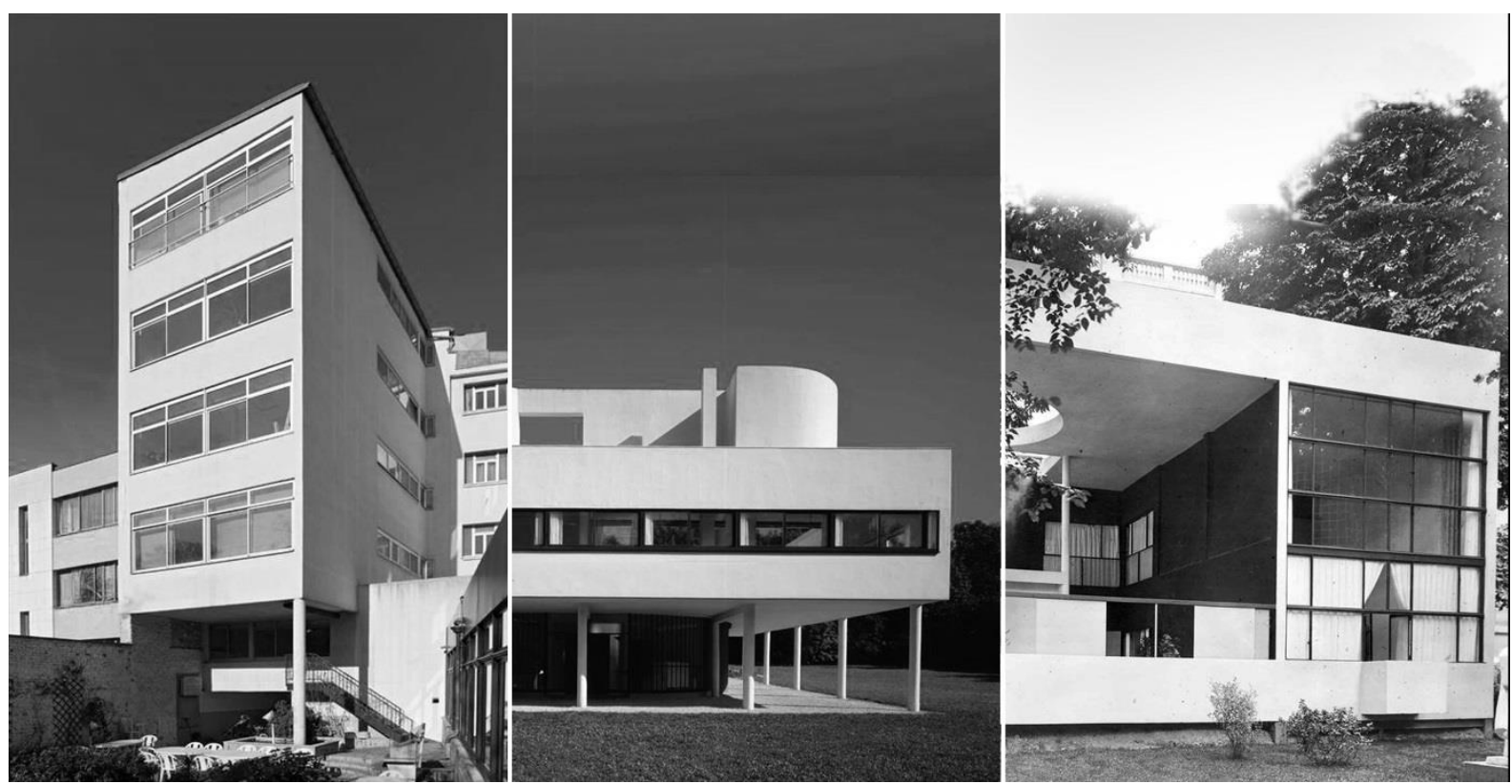

2. Three types of buildings compose the Modern Style of the "Heroic Period" of Le Corbusier in the 1920's: Residential Blocks, Villas and Pavilions.

The "white houses" of the years 1922-1927 that crystalized the Modern Style were no more than a handful. Starting with the 1922 Ozenfant House \& Studio and ending with the realization of the Villa Savoye in 1931, the undisputable peak of these experimentations. The houses gradually composed a very specific style that nevertheless, allowed wide variations. Some specific characteristics that demonstrate the rigorous formal vocabulary of these buildings were:

- the white plastered surfaces

- the ribboned-windows

- the smooth, perfect finishes

- the pilotis and more specifically, the circular slender concrete columns

- the use of windows and volumes for a composition of the façade with an elementaristic effect, not unlike the De Stijl exponents of the epoch.

The houses also popularized the use of the golden number. This however was not considered as a reference to neo-classicism, but as an embrace of the mathematical nature of beauty that the modern style aimed for, through the use of proportionality and ergonomy. It is also key for understanding that from its beginning, the original modern style of Le Corbusier was prospectively determined to have a formal aspect. In contrast to the contemporary Bauhaus initiative that claimed a modern style that derived from functional uses, in Le Corbusier we can recognize his architecture works artistically destined in the same way as he has a priory defined the equivalent style of purism in his paintings.

The second series of buildings, the social housing projects are linked less through formal elements and more in matters of design methods in combination with their social mission. The 1922 project for the city of three million habitants opened the way to a wider understanding of the Dom-ino archetype in new a social context. Its formal vocabulary was much harsher than his contemporary villas but in a way more simple and disciplined. Such urbanistic projects that Le Corbusier subsequently produced gave notoriety to his practice while also justified the formation of a modern architectural style since it could impose a modern "lifestyle" as an instrument of authority 
in the "machine age". These projects made clear that Le Corbusier's modern style was not limited to the scale of the villas but could even be applied to the size of a whole city. The housing project in Pessac from 1925 was representative of his efforts and displays paradigmatically the problems that the implementation of modern style in a massive scale would have.

There are several points that should be discerned regarding the formal aspect of this series of buildings. Firstly, despite the economic limitations and the high degree of standardization, Le Corbusier managed to feature in these buildings his 5 points of architecture. This meant that a stylistic cohesion could be maintained in a totally different scale of size and budget and in a different intensity as well. Standardization and homogeneity were also exhibited as stylistic features, something that could not be argued for his villas. A sort of customization offered to the inhabitants also had a formal impact that characterized these projects, as for example was the case in Pessac. Most of these housing projects are rarely perceived from an artistic viewpoint but it could be said that they were the first to test the adaptation of the middle class in modern aesthetic standards perceiving the modern style as the materialization of a communal feeling of progress rather than an artistic novelty.

If the Villa Savoye could be noted as the peak of Le Corbusier's villas, an equivalent pivotal project for his mass housing projects would be the Cité de Refuge of the Armée du Salut built between 1929 and 1933. With a strategically subtle composition of elements the Cité pinpoints the social aspect of the new style, with the innovative building functioning perfectly in terms of space, temperature and light; paired with an intense artistic presence. This project was the first to signal the institutional implementation of Le Corbusier's ideas. From this moment on he had already departed his visionary projects beyond housing, towards "Public palaces" instead, in projects such as the League of Nations (1927), the Mundaneum (1929) or the Palace of the Soviets (1931). Although these projects ended in fiascos, the Cité provided a valid prototype for a new set of communal buildings in the 1930's, such as the Pavilion Suisse. These projects were mainly variations on the theme of the glass slab with attached communal elements at ground level ${ }^{12}$. All of them, affirming undisputedly the service of the machine-house and concluding the evolution of the Dom-ino and Citrohan schemes in clearly dictated forms and methods of construction.

The third category of buildings that completes Le Corbusier's "Heroic Era" were the three ephemeral pavilions: the pavilion for L'Esprit Nouveau (1923), the Nestle pavilion (1927) and the Pavilion de Temps Nouveaux (1936). This category is not matched with the importance and influence the villas or the housing projects had. It does however emerge as an exemption. These three projects innovate in a small scale laying the foundation for a flexible directive of the Modern Style. At the Exposition Internationale des Arts Décoratifs of 1927, the Pavilion de L' Esprit Nouveau popularized the concrete cell and manifested the image of the new architecture delivered of the applied arts. The Nestle Pavilion did the same for metal and glass structure. Demountable and functional, paired with the use of graphic design, these structures operated in a totally different context of appearance than Le Corbusier's other works. In the pavilions we can trace not a style, with the sense of set of architectural forms, but more of a strategy of promotion and display of modernism as an experiential process and cultural event integrated in a degree zero of means or time limitations, but nonetheless distinct. Throughout the 1920's it could be said that the three typologies of villas, housing projects and pavilions illustrate the complete assurance of Le Corbusier's formal system in maturity and their evolution in the dawn of the 1930's even hints at reasons for changes in style that were imminent.

The 1930's and more precisely, since the completion of the Villa Savoye, a neo-primitive period for Le Corbusier's work commenced; still in the context of modernism. Projects such as the Villa Mandrot and the Villa

${ }^{12}$ Curtis, Wiliam, Le Corbusier: Ideas and Forms, London: Phaidon Press, 1980. 
"Sextant" introduced the use of vernacular masonry with the trademark white coating missing. Housing projects such as the Immeuble Molitor and the Pavilion Suisse, portray a new materiality for bigger projects as well, with the use of glass brick, masonry and brick walls, wooden and stone cladding. Novel forms were introduced as well, such as the arced interiors, the sculptural supports and the sophisticated furniture pieces. Not quite as distanced to his earlier forms, Le Corbusier's realized projects from 1933 to 1944 display a break with the pure forms of his 1920's architecture and reflect the disturbing years before and during wartime.

\subsection{Formalistic Associations (1944-1965)}

It is ironic that the Unite d' habitation designed in 1945, inaugurates Le Corbusier's formalistic period. This project brings together all the conceptual features that a "social engineer" would sought to solve. But artistically the post-war period meant for the modern movement and consequently for Le Corbusier (or was it vice-versa?) a turn for the notion of style as "total design"- controlling, structuring and solving new needs- to a return to style's understanding as the "synthesis of the arts". Le Corbusier's response was a creative tour de force in structuring a much more personal and experiential set of forms that resulted in his expressionistic attempts. The most distinctive and meticulous set of forms was the modern style of brutalism. The first Unite in Marseille (19451952) along with the factory "Claude et Duval" (1946) propelled the new style that instantly became a trend for public buildings and since $1953^{13}$ was promoted as a distinctive, counterbalancing style to modernism itself. The forms were typically reminiscent of infrastructures and thus, familiar for public use. This is also the factor that rendered them presumably socialistic. Of course, for Le Corbusier brutalism was more an artistic endeavor than a moralistic argumentation. With the Convent of La Tourette (1960) being his most representative of his brutalistic buildings in France he moved on in several other series of buildings still in the context of this style. The brick houses, such as the Maison Jaoul (1951-1956) or the Villa Sarabhai (1951), are the most distinguishable of such a variation on brutalism. While the three museums in Ahmedabad, Chandigarh and Tokyo are almost identical and conceptual descendants of the Mundaneum project. All of the brutalistic buildings share in common the brutal appearance of their materials (naturally), they feature the use of proportions dictated by the Modulor and bear applied decorations by Le Corbusier himself or his collaborators.

A special category of Le Corbusier's brutalistic style would be the projects he produced in India. And that is because, the forms that he produced there sparked a widely distinctive style of post-colonial civic architecture. Whether it is debatable or not if Le Corbusier structured this style specifically for Chandigarh and the country of India, retrospectively is irrelevant, since it is now a trademark of the city's governmental facilities. A couple of formal characteristics, separate this category from the rest of Le Corbusier's brutalistic work. The most apparent is the remarkable symbolisms while more recognizable is the extensive use of the brise soleil not as an element applied on the surface of the building, but as the façade itself. Another one is the playful complexity derived from problems of sun exposure and air circulation.

Apart from the brutalistic buildings, Le Corbusier's late plastic period generated a great number of ambiguous and non-classifiable projects in terms of architectural style. The Notre Dame du Haut Chapel at Ronchamp (1950-1954), probably Le Corbusier's best-known building, is proof of his ability to lay a complete total work of art, separately from his main stylistic engagement with brutalism. Ronchamp, along with the Philips Pavilion (1958), the Saint Pierre Chapel (1960-2006) and the Heidi Weber Museum (1960) portray a technological expressionism, totally a rebellious towards the International Style. During the decade 1955-1965 instead of a

\footnotetext{
13 The term "new brutalism was used by Alison Smithson in 1953, while the book "New Brutalism: Ethic or Aesthetic?" (1966) brought together a group of architects that whose work was characteristic of the style.
} 
rigorous stylistic commitment, Le Corbusier's Atelier “de la recherché patiente" was evidently striving for a constant succession of forms. And it did so in a spectacular way. It could be noted that Ronchamp provided a model for a 1960's neo-plasticism as well as a harbinger to post-modernism, the Philips Pavilion seems like a predecessor of 1990's and early 2000's fascination with parametric design and blobitecture while the Heide Weber Museum seems like a mixture of the contemporary high-tech style and the light modernism of the Eames. Lastly, the St. Pierre chapel is yet to be comprehended as to the decisions that led to its development, though it strikingly precedes the fascination of monolithic structures in recent years, in comparison for example with Koolhaas's Casa da Musica (2006).

If we were to speak over Le Corbusier's regionalistic influences we should place them in context of his expressionistic attitude since the local elements seem to have been used more in order to break with pure modernism's homogeny and less as an attempt to apprehend the regional culture as the later movement of critical regionalism did. If his first period the regional influences where placed under consideration, questioning and dismissal, in his third period they are summoned to enrich the expressionistic characteristics of his projects through the hand-mafe, the textures, the colours etc.

In contrary to his 1920 machine aesthetic, by the end of his life he had adopted practically the opposite approach: a steady, organic, artisanal approach to building, and a healthy respect for history and tradition. Of all his late stylistic experiments notwithstanding, there is no "Modern Architecture" to which he was faithful-only the basic principle of being critical and creative. It is a matter of contention, whether Le Corbusier's emotional defense of architecture' s status as an art was the weakness or the strength of his theoretical system. It was a system that entangled him in contradictions in its attempts to find architectural and technical solutions to the problems of industrialization, aesthetics and mass-culture. These contradictions are bound to be expressed in terms of style, being modern, brutalist or post-modern, they are the architectonic metaphors of industrial reality.

\section{Part 2. Style in Le Corbusier's Life}

Although Le Corbusier's architectural styles shifted, mutated and unfolded in every direction, the expression "in Corbusian style" is only comparable to "Paladian style", as the only architectural styles to be attributed to one sole creator. This is only representative of Le Corbusier's influence not only through his actual work but through his presence as an artistic persona and the man that personified $20^{\text {th }}$ century architectural anxieties.

It is known that Le Corbusier went through great pains in order to structure his profile but the question of what constitutes the brand "Le Corbusier", has come to pass in the realm of mythology even for the $21^{\text {st }}$ century, where Le Corbusier's mystical figure continues to dazzle us. And this was part of the plan, for although Le Corbusier was determined to be well known, he was also determined not to be known well. He never added an autobiographical memoir to his extensive writings, and he disclosed so few personal details that he seemed to have no private life at all. However, one thing everyone knew about him was his relentless Protestant work ethic, befitting the son of a Calvinist watchmaker ${ }^{\mathbf{1 4}}$.

Le Corbusier was documented to be shy, but nonetheless a cunning self-promoter imposing himself as a trademark from as early as 1917, when he started living in Paris and entered Perret's “Thursday luncheon meetings of artists" and Max Dubois's "Sunday outings" "15. His public image was his biggest achievement: the

\footnotetext{
${ }^{14}$ Filler, Martin Moos, Makers of Modern Architecture, New York Review of Books, New York: 2007.

${ }^{15}$ Lawman, Joyce, Le Corbusier 1900-1925: The Years of Transition, Ph.D. submitted at the University College of London, 1981, pp 229.
} 
Le Corbusier project that was incomparably designed and executed. A short description of his professional titles and endeavors does shed a light on his ascension to his hard earned status.

LE CORBUSIER /CHARLES EDOUARD JEANNERET $1887-1965$
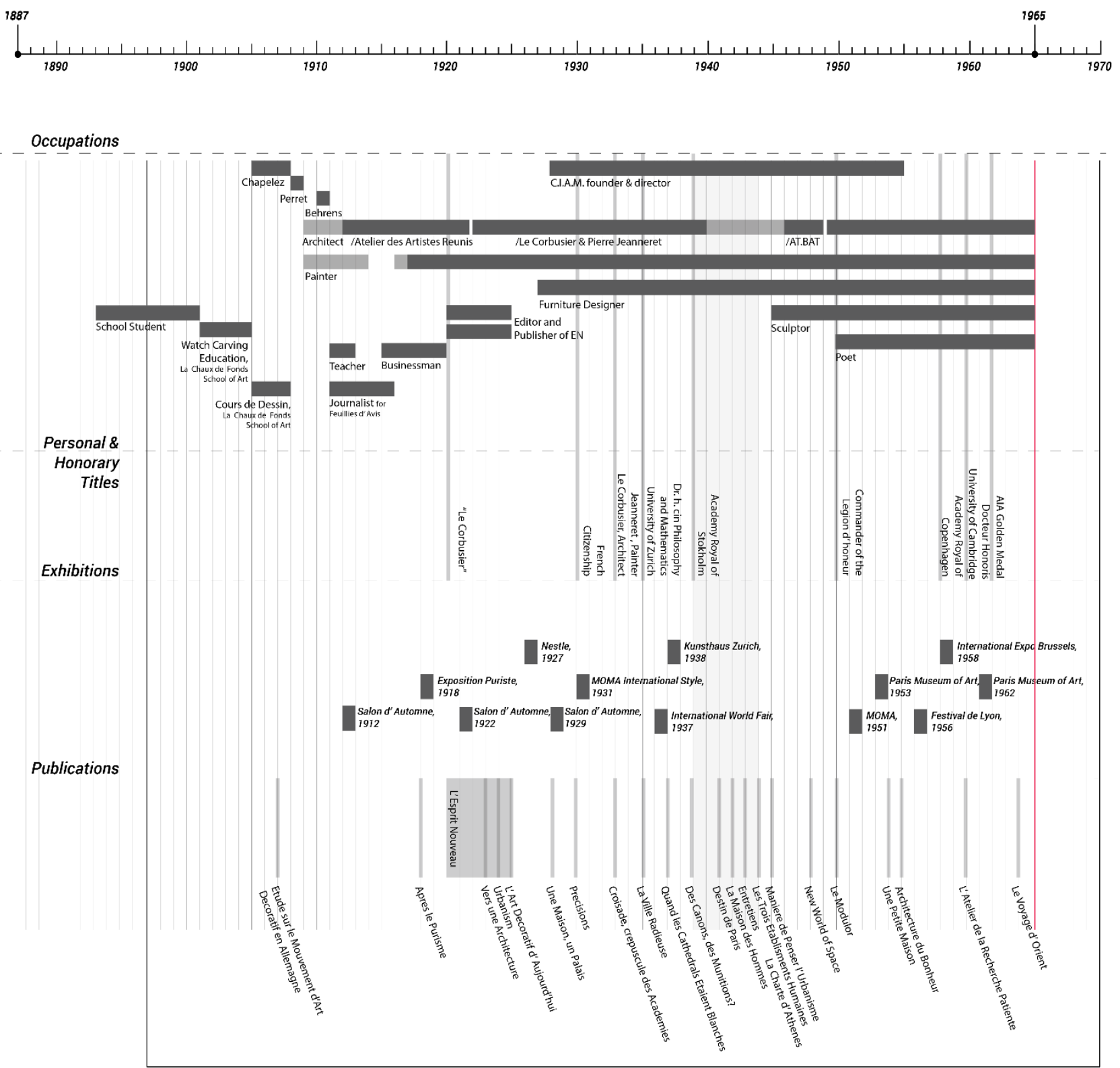

3. Classification of Le Corbusier's titles of occupation or of honorary achievements in parallel with his major publications and exhibitions.

His early years at La Chaux-de-Fonds and Paris seem quite extraordinary considering the change of his occupations. At first destined to become a watch carver, young Jeanneret was closely mentored by a couple of important artists through his passing from interior design, architecture, painting, teaching, journalism, entrepreneurship and then back to architecture again. His hiding his descent and later portrayal of himself as selfinstructed and exquisitely talented sheds the fact that by the time he was almost thirty, he himself did not had a clear image of what he wanted to present himself as. Most compelling was his dilemma between architecture and 
painting. And it was probably this dualism that led to his adoption of the pseudonym, "Le Corbusier", in 1920 and the distinguishing of the uses of his name according to his featured profession by 1930: Jeanneret for painting and Le Corbusier for architecture.

His swift rising among the artistic and architectural circles of Paris proves his intelligent dealing and expanding his contacts as well as a high production of work being architecture, urban design, writing or painting. It is also clear that he claimed ideas produced by others as his own but we have no image as to what extent he acted deliberately this way. Several people have posthumously expressed their resent over Le Corbusier's neglect of honoring them. They did however administered several aspects of Le Corbusier's versatile identity. Max Du Bois and Auguste Perret introduced him to concrete technology, Ozenfant brought out the painter in him, Perriand the furniture designer, Savina the sculptor while lastly, Pierre Jeanneret's mysterious figure conceals us the extent to which he fueled the architectural vigor of his cousin ${ }^{16}$. During the years 1949-1965 at Le Corbusier's atelier at rue des Sevres, a large team of young and talented people assembled beside him providing him with formal as well as conceptual contributions over his projects. The designs of Ronchamp (Maisonnier), la Tourette (Xenakis), the Carpenter Center (J. de la Fuente) or the Venice Hospital project (Julian) bear witness to the importance of his disciples and collaborators. Nonetheless, the image of the black clothed crow-like figure, with the owl-like glass and the beret or pipe occasionally placed him at the center of attention.

Le Corbusier's keen eye for acquaintances as well as his international appeal that led to the grand scale of his post-war commissions reveal Le Corbusier's keen eye for political acquaintances. It is an achievement how he managed to have commissions for the League of Nations, Soviet Russia, Vargas' dictatorial Brazil, the UN in New York, and in the midst of the cold war constructing Punjab's capital in India. It also of great wonder how he managed to hide his affiliations with the Vichy government that became known only recently. Le Corbusier's style seems to be more disciplined in matters of his seducing his clientele and befitting of his following. What is nowadays being studied under the label of personal brand or brand-image and is often misused instead of the term "style"-for they are both about specialization-was spearheaded by Le Corbusier. And it was his personal relationships that kept his office running and alternate forms and construction methods with patient clients who could overlook the impracticalities of Le Corbuisier's capricious designs and temperament.

Despite his careful positioning, one think that served foremost his self-projection and that we can apprehend as largely internal and personal was his ceaseless production of writings. Whether books, pamphlets, journals, articles or his extensive mailing correspondences, writing was for Le Corbusier the main instrument of identification. It is the link that connects his diverse forms of his architectural projects under the roof of -isms: "modernism", "purism', “functionalism" or "brutalism". The spirited literature is the context upon his styles were grouped keeping his audience hooked on each of his ventures and still considering them part of a compact rationale. Largely inspired by Ruskin, Le Corbusier considered the architect foremost, an intellectual, an artisthero with deep knowledge of philosophy and literature. It is a fact that Le Corbusier's identity card stated himself as an "homme des lettres". With no more than 57 actually executed projects, the more than 50 books he produced were his most immediate way of achieving a status of a prudent, well-advised and innovative architect. His book The Athens Charter is an exemplary occasion when he capitalized on the momentum of the CIAM when acting alone he published the material that was produced by the organization as a whole. In his early years, books were also his way of leaving his provincial hometown, being funded to travel in order to write reports (trip to Germany) or contributing to journals (voyage d' orient), while later as an editor and publisher, through the

${ }^{16}$ Le Corbusier et son atelier, rue de Sevres 35, Oeuvres Completes vol. 7: 1957-1965, Zurich: Les Editions d' Architecture, 1977. 
publication of L'Esprit Nouveau Le Corbusier's was able to criticize, promote and censor others and more effectively his own profile. Presenting himself as the prophet of the modern movement.

Le Corbusier's Euvre Complètes displays a stunning work done in post-production. It also features extensive photographical documentations of himself in social meetings, such as his encounter with Einstein. Photography, being precise, calculated, rational and expressive was from the start the ideal collaborator for an architect vacillating between an engineer and an artist, adopting "seeing" as his central narrative. Though he abandoned the perspective of being a professional photographer himself, during his lifetime Le Corbusier hired his personal photographers placing often himself as the object to be photographed. To name just a few of them, Le Corbusier's most famous photographers were: Gravot, Burri, Boissonas, Steiner and Herve with whom he either extolled or denounced for the way they portrayed him or his work, while he demanded personal control of the photographer's material.

Finally, Le Corbusier's orchestral manipulation of his all-embracing identity was assisted by his manifold artistic interests and mainly his easiness with painting. In the 1920's there was a strong dependence of much early modern architecture on painting. Cubism, Constructivism, De Stijl and Purism were all instrumental in the creation of the various ${ }^{17}$ currents of modern architecture. His experience in structuring with Ozenfant the painting style of purism, through exhibitions, publications and public relations, definitely predisposed him for his leading the waves of the modern movement. And while his 1920's and 1930's years where marked by his dramatic separation of architecture and painting occupancies, his post-war period revealed his dexterity in orchestrating his multi-faceted talents in complete works of art (gesamtkunstwerk), therefore expanding swiftly his stylistic vocabulary. After the 1940's whence the opposition of architecture to be unified with the visual arts had started to shift, architects turned to painters and artist for collaboration. But Le Corbusier needed not such a thing. He supplied his buildings with murals, decorations, sculptures, furnishings and interior designs, even composing the "modulor" and the "claviers des couleurs" as his stylistic guides. In contrary to his earlier manifestos, this attitude reveals a much more form-oriented effort. In combination with his work experience this all-inclusive artist was led to his most personal undertakings in Ronchamp and Chandigarh. Perhaps one of the reasons that Le Corbusier is not as publicly recognizable nor has he ever been comprehensibly classified as he should be: he simply did too much. Rather than sticking to a single, easily identifiable style, his work continually evolved $^{18}$.

\section{Conclusion}

Mainly, Le Corbusier used the word "fait" (effect, event) instead of the word "style", such as in his expression "le fait brutal". And most famously he attacked the notion of style in his frontispiece of the chapter "Eyes that do not see", from his Vers Une Architecture (1923): "Architecture is stifled by custom. The styles are a lie. Style is a unity of principle animating all the work of an epoch, the result of a state of mind which has its own special character. Our own epoch is determining, day by day its own style. Our eyes, unhappily, are unable yet to discern it."

Le Corbusier did not consciously set off to structure a style. He did however pioneer several ones. What he was determined to do from the start was to establish a doctrine that would affect all of modern life. By 1910 in a letter to his friend and mentor W. Ritter, he writes: "General culture today, when no single style reigns, seems to

\footnotetext{
17 “The Paintings and Sculptures of Le Corbusier”, Guedes A.. In Architecture SA / Argitektuur SA Johannesburg: JannuaryFebruary 1988 .

${ }^{18}$ Rose, Steve, The many Contradictions of Le Corbusier, theguardian.com, 2008.
} 
me to be the basis for everything". Therefore, it was the absence of a style that was motivating him. Even though he represented modern era's disapproval of the $19^{\text {th }}$ century styles, the question "in what style he should built" was laid before him: a modern style could emerge, he wrote, but not from copying styles of the past, although at the same time being aware that he himself was at a loss to produce such a style $(1914)^{19}$. Would not he be surprised that fifty years later, neither we can grasp the full meaning his "Corbusian style"? For we are still under its spell. In our affluence of styles, one think we know for sure is that they are "Corbusian" ${ }^{20}$ children.

${ }^{19}$ Le Renouveau dans l'Architecture, Jeanneret, Charles-Edouard. In L'Oeuvre, vol 2, La Chaux-de-Fonds : 1914.

${ }^{20}$ Habraken, John, Palladio's Children, London:Taylor \& Francis, 2005. 